\title{
Performance and Feasibility Study of a Novel Automated Catch-Hauling Device Using a Flexible Hose Net Structure in Set-Net
}

\author{
Qiao Li ${ }^{1}$, Yue Li ${ }^{1}$, Shuchuang Dong ${ }^{1, *}$, Yoichi Mizukami ${ }^{1}$, Jialin Han ${ }^{2}$, Takero Yoshida ${ }^{3}$ and \\ Daisuke Kitazawa ${ }^{1}$ (D)
}

check for

updates

Citation: Li, Q.; Li, Y.; Dong, S.; Mizukami, Y.; Han, J.; Yoshida, T.; Kitazawa, D. Performance and Feasibility Study of a Novel Automated Catch-Hauling Device Using a Flexible Hose Net Structure in Set-Net. J. Mar. Sci. Eng. 2021, 9 , 1015. https://doi.org/10.3390/ jmse9091015

Academic Editor: Sarat Chandra Mohapatra

Received: 4 August 2021

Accepted: 14 September 2021

Published: 16 September 2021

Publisher's Note: MDPI stays neutral with regard to jurisdictional claims in published maps and institutional affiliations.

Copyright: (C) 2021 by the authors. Licensee MDPI, Basel, Switzerland. This article is an open access article distributed under the terms and conditions of the Creative Commons Attribution (CC BY) license (https:/ / creativecommons.org/licenses/by/ $4.0 /)$.
1 Institute of Industrial Science, The University of Tokyo, 5-1-5 Kashiwanoha, Chiba 277-8574, Japan; liqiao@iis.u-tokyo.ac.jp (Q.L.); utokyoyueli@gmail.com (Y.L.); yomi@mpd.biglobe.ne.jp (Y.M.); dkita@iis.u-tokyo.ac.jp (D.K.)

2 Aerospace and Marine-System Engineering, Osaka Prefecture University, 1-1 Sakai, Osaka 599-8531, Japan; kankarin@marine.osakafu-u.ac.jp

3 Department of Ocean Sciences, Tokyo University of Marine Science and Technology, 4-5-7 Minato, Tokyo 108-8477, Japan; tyoshi3@kaiyodai.ac.jp

* Correspondence: dongsc@iis.u-tokyo.ac.jp; Tel.: +81-47-7136-6967

\begin{abstract}
The labor-intensive catch-hauling method in set-net fisheries faces problems of lower productivity, lower efficiency, and higher operational risk due to aging problem and labor insufficiency. To solve such problems, a novel catch-hauling device using the flexible fire hose and net (hose net), which is placed in the box chamber, was proposed in this study. The hoses were inflated with air injected into one edge of the hose net, and the buoyancy force increased: the net gradually floated up, cornering the fish in the opposite edge. To corner and harvest the fish efficiently and safely, the changing formation and motion parameters of the hose net are significant. A series of floating up, sinking experiments, and catch-hauling tests were conducted to evaluate the performance of this device. The results showed that the hose net could gradually float in an ideal form and sink smoothly through natural exhaust and stretched on the bottom of the water tank. The time spent and average speeds in floating and sinking processes varied with air pressure and airflow rate, allowing the hose net motion to be controlled in practice by adjusting the airflow. Through the catch-hauling test using live fish, most of the fish were directed into the fish bag. Two main capture failure phenomena were also observed. Overall, this newly developed automated catch-hauling device is expected to be successful for use in modern fisheries.
\end{abstract}

Keywords: set-net; flexible hose net; water tank experiment; catch-hauling testing; automated catch-hauling device

\section{Introduction}

The set-net is a type of stationary pound net [1] that is frequently used in the coastal areas of Japan, South Korea, and Canada to passively capture fish [2-4]. Compared with the traditional trawl, set-net fishing is an efficient fishing method without excessive fuel consumption $[4,5]$. A set-net mainly consists of leader net, playground, ascending slope net, and box chamber net. In some set-net, there is a fish bag net attached to the box chamber net. The leading net directs the fish to swim into the set-net and is collected in the box chamber net (Figure 1). 


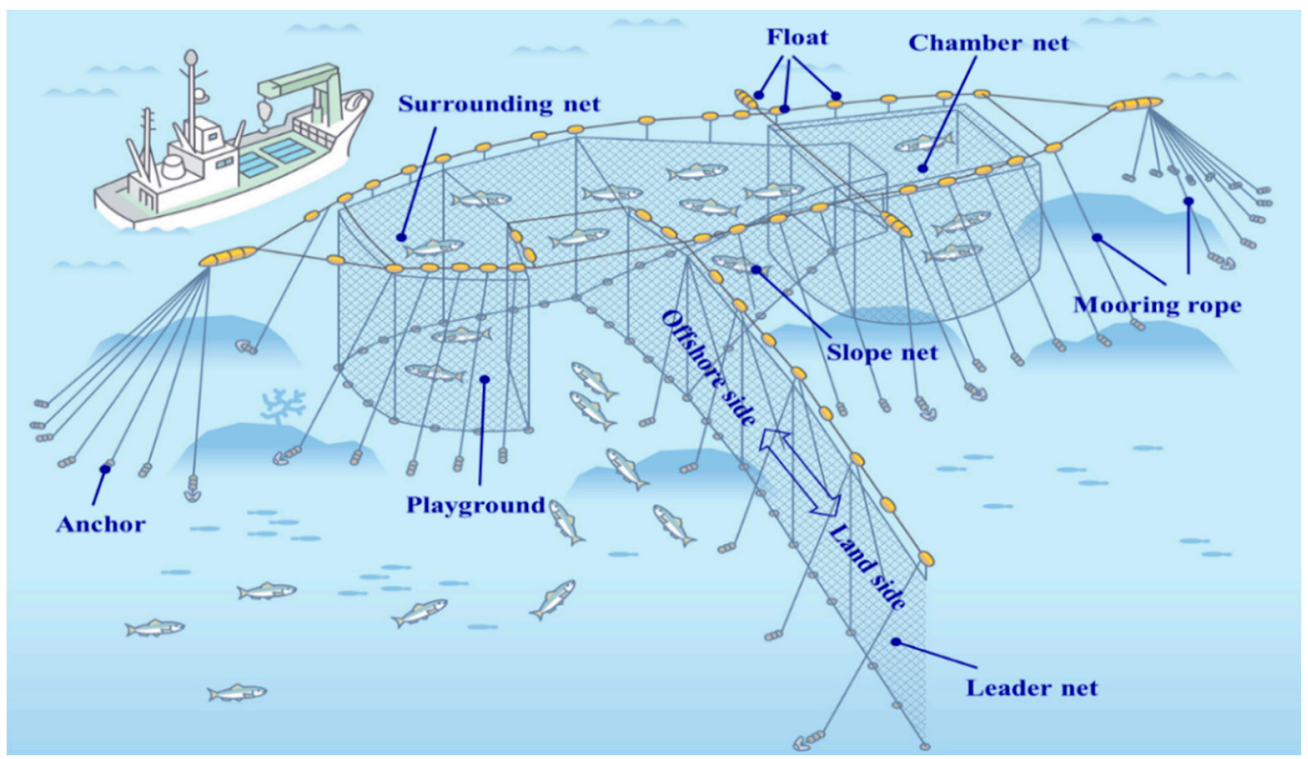

Figure 1. Structure of a set-net reproduced from [6].

The set-net fishery is an important, accounting for approximately $40 \%$ of coastal fisheries catch in Japan [7], and is positioned as a crucial industry in the region to create much employment. An important issue in the set-net fishery is how to efficiently capture the catches in the box chamber net and harvest high quality catches. In particular, live capture techniques enable the operators to add value to the catches with more choices to sell immediately, control supply to the market, or hold and grow / fatten [8]. The conventional method uses two fishing vessels to haul up the box chamber and collect its catches. It is easy to harm the fish body, and more importantly, it is inefficient and requires a large number of workers. For example, for a large-scale set-net with a chamber net length of more than $100 \mathrm{~m}$ and a net height of tens of meters, the hauling operation requires more than ten operators because it is too heavy and large. However, the Japanese fisheries industry is currently facing a challenge: the shortage of successors caused by an aging population. A few operators, at least one operator, will be sufficient if new technology is implemented. Therefore, the development of an automated catch-hauling system is necessary to address this issue.

Several studies focused on the capture process in set-net and have investigated the fish school behavior and hydrodynamic characteristics in set-net through water tank experiments, numerical simulations, and sea trial experiments [3,5,9-12]. To the best of our knowledge, only a few studies have reported on automated hauling devices. For example, airbags placed inside the box chamber net were first tested in the 1920s [13]. Fukahori et al. [14] proposed a technique using rubber tubes installed beneath the box chamber net as technology progressed. With air injected into one side of the tubes, the tubes could float gradually and haul up the box chamber net.

Nevertheless, rubber tubes and connecting parts worked well when they were new, but they become no longer waterproof after a few years (usually 4-5 years). Water gradually accumulates in the air floats and belt hoses, making it difficult to float up and sink. Largescale operations require identifying and repairing defective parts, which were difficult and new parts were costly. Hence, the method does not prevail because price and maintenance cost are high. A type using several polyethylene pipes was not practicable because it was uncontrollable if the length of the pipes are longer than $100 \mathrm{~m}$, and the fish were easily trapped in between [15], resulting in a lower harvesting rate. In the coastal trap-net fishery in the northern Baltic Sea, air pontoons are successfully used to raise chambers during nethauling $[7,16,17]$. A concept of a net-like structure made of flexible hoses installed below the box chamber net was proposed in previous studies [18,19]. This structure was arranged and connected similar to a brick form. Since the diameter of the flexible hoses available at 
low prices was small, the hose net contains many connections. Fish are harvested almost every day; hence the large change in pressure acts on the connectors. If a connector is broken, the air will leak from the broken connector, which is not easily repaired in routine operation. In addition, the buoyancy was not enough to support the floating up of the whole box chamber net. The following types of automated net-hauling systems were developed based on this concept to improve these remaining problems. A water tank experiment was recently conducted for the hose net, which comprised five long hoses connected with each other [20]. The advantage of this hose net is that it reduces the number of couplings. However, air injection and ejection through seven input vents were difficult to manage because air tubes became entangled during net-hauling operations, and airflow was obstructed at the bending portions, limiting the net's floating speed. Furthermore, due to the asymmetrical configuration of the line, the hose net did not float symmetrically.

Therefore, we improved the convenient on-site operation and catch-harvest performance of the automated catch-hauling device and proposed a novel form using flexible fire hoses and fishing cover netting (hereinafter referred to as hose net) [21,22]. As shown in Figure 2a-c, the innovation here is how the flexible hose net is placed on the bottom netting inside the box chamber net and does not require hauling up the box chamber net; as air is injected into hoses, only the inner hose net device will be raised, and then fish will be induced to the fish bag. It requires less buoyancy, resulting in a lower cost of the system. Furthermore, the hose net can be separated and maintained easily.
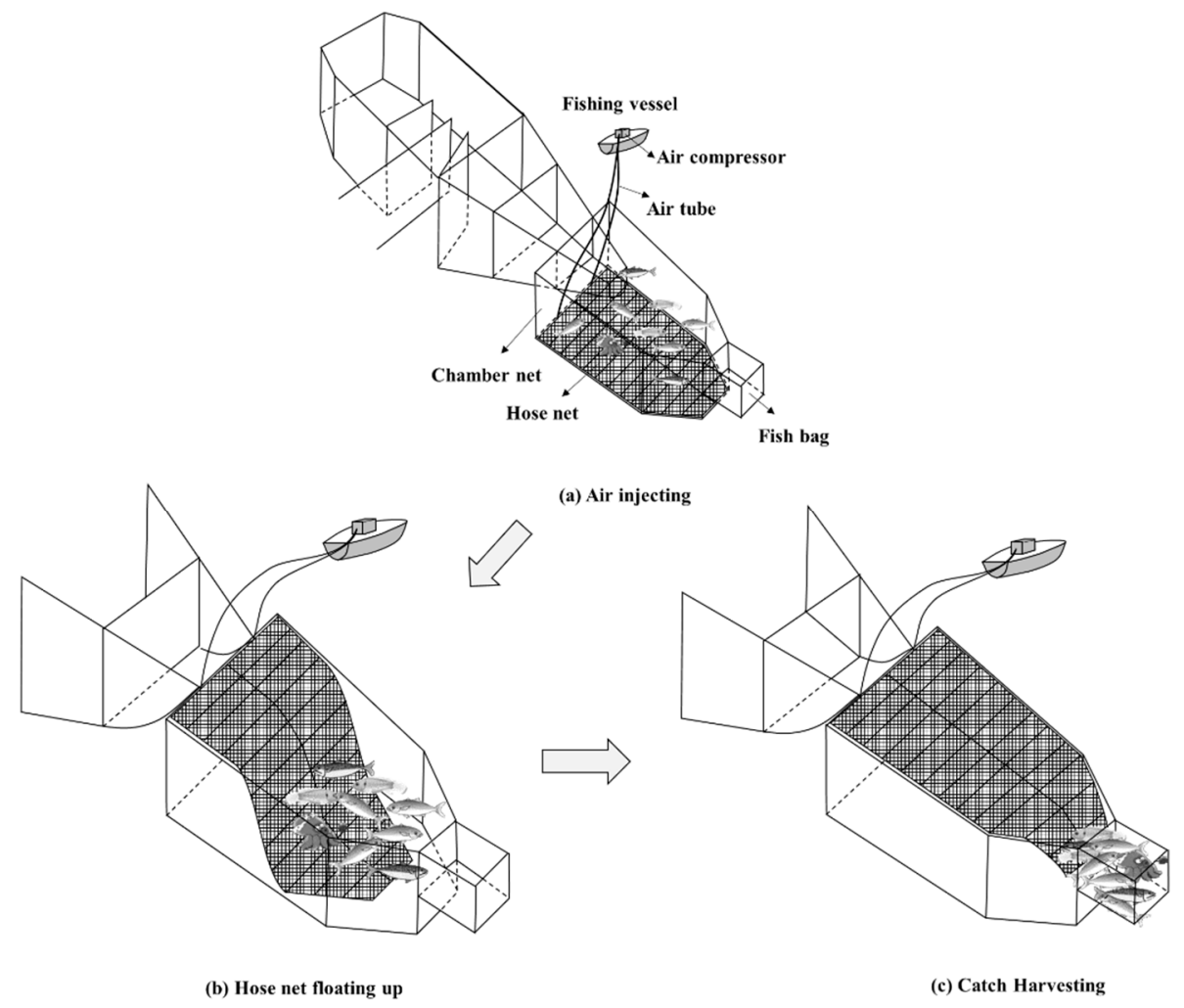

Figure 2. Catch-hauling process of the novel automated hose net system.

As a result, a new system offers cost and maintenance benefits. However, the performance of the system should be assessed to ensure its functionality. The hose net buoyancy and weight should be adjusted such that it may float up the cover netting and sink with its own weight. To achieve the practical function of efficiently cornering the fish, the deformation and motion of the flexible hose net should be examined. This research used a series of water tank tests to confirm the newly created automatic catch-hauling device's ability to float up and sink. When using this new approach to catch live fish in a tiny water tank, we also examined fish school movement. 


\section{Material and Methods}

\subsection{Floating Up and Sinking Experiments of Hose Net}

The required performance of the hose net is to ascend in a shape that drives the fish and settle immediately after harvesting by natural exhaust. As the first step, we only conducted a floating and sinking experiment of the hose net without considering the box chamber net. The water tank experiments were performed in the Ocean Engineering Basin at Chiba Experiment Station of the Institute of Industrial Science, University of Tokyo. The Ocean Engineering Basin can generate waves, current flows, and winds, and is $50 \mathrm{~m}$ long, $10 \mathrm{~m}$ wide, and $5 \mathrm{~m}$ deep. The lifting plate can adjust the water depth in a part of the basin between 0.5 and $5 \mathrm{~m}$.

\subsubsection{Novel Automated Catch-Hauling Device Model}

Figure 3 shows the structure of the current hose net. The hoses used in this device were fire hoses with the same diameter and different lengths, and they were connected; a cover net was attached to the hoses (Figure 3a). There are many candidates for flexible hoses; a fire hose was chosen because it is used and inexpensive. There are only two air input vents, making it easier to be operated. The new hose net is installed in the box chamber net, which means that it does not have to haul up the whole box chamber net, and the buoyancy can be saved greatly. The current hose net has several advantages: (1) By using T-shape connectors, air can flow smoothly through the hoses without being impeded, time for floating up and sinking can be shortened, enhancing the operational efficiency. (2) The hose net is easy to control because there are only two air input vents. (3) Because the newly developed hose net does not need to haul up the whole box chamber net, the buoyancy can be saved greatly, and the operational efficiency is enhanced.

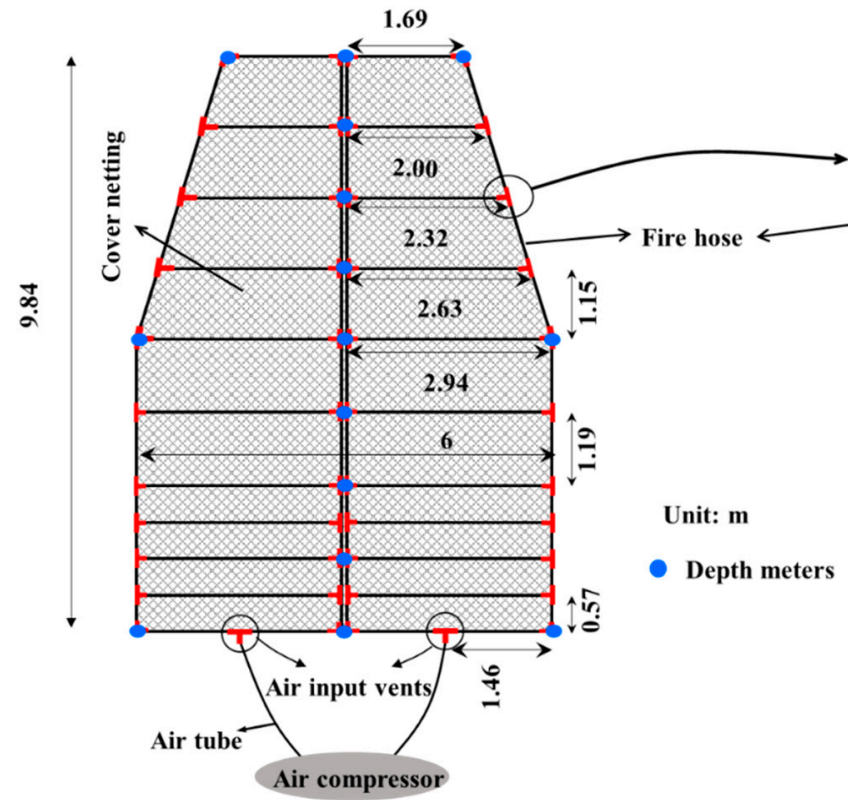

(a) Structure of hose net

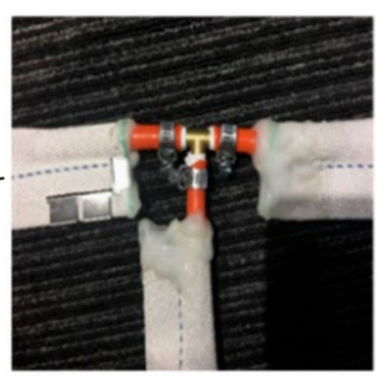

(b) Hoses connected with Tshape connectors

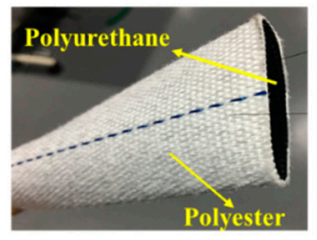

(c) Materials of fire hose

Figure 3. Structure of the newly developed hose net.

A full-scale set-net will be used in a coastal area of Japan with a water depth of $28 \mathrm{~m}$. The set-net has a box chamber net with a length of $59 \mathrm{~m}$ and a width of $36 \mathrm{~m}$. The size of the hose net is the same as the bottom net of the box chamber. The Froude scaling method was chosen for the test, the geometric scale ratio was set as $1 / 6$. The dimension of the $1 / 6$ hose net model is shown in Figure 3a. The length of the hose net model is $9.84 \mathrm{~m}$, width is $6 \mathrm{~m}$. The depth of water in the experiment is $4.6 \mathrm{~m}$. The hose is made of polyurethane coated with twill-woven polyester and is the same structure as the actual hose. This double 
structure enables the hose to be waterproof and protected from friction (Figure 3c). The hose has good wear resistance. Chain steel or lead is used in the actual sea, whereas steel was selected as the experimental material.

The full-scale cover net will be made of nylon with lead, with a diameter of $1.44 \mathrm{~mm}$ for the twine and a mesh size of $20.2 \mathrm{~mm}$ for the mesh, depending on the size of fish that fishers wish to release. The cover net in the experiment was made of polyester to match the projected full-scale cover net's solidity ratio.

Since the scale ratio is $1 / 6$, the ratios of volume and force are $1 / 220$, considering the difference in water density in the water tank and actual sea. The buoyancy is determined to haul up the ascending slope net and close the gate of fish passage. The flexible hoses are densely deployed in the side of the air input. The function of additional weight is to make the hose net sink smoothly by the natural exhaust, which means that the air flows out of the hose net without a vacuum because of the difference between the hose net inner pressure and the atmospheric pressure when the two vents of the hose net are opened. The buoyancy of the hose net decreases with air flowing out and the whole hose net begins to sink gradually on the end side. We adjusted the additional weight through preliminary trials since the buoyancy and weight in floating and sinking activities should be the same. The extra weight for the hose net is supposed to be approximately $40 \%$ of the maximum buoyancy, but in this investigation it was increased to $42.5 \%$. Table 1 summarizes the physical properties of the $1 / 6$ model and the actual net.

Table 1. Physical parameters of the model and actual hose net.

\begin{tabular}{ccc}
\hline Items & 1/6 Model & Actual Net \\
\hline Length $(\mathrm{m})$ & 9.840 & 59.000 \\
Width (m) & 6.000 & 36.000 \\
Inner diameter of the hose (m) & 0.025 & 0.150 \\
Outer diameter of the hose (m) & 0.028 & 0.168 \\
Volume $\left(\mathrm{m}^{3}\right)$ & 0.044 & 9.504 \\
Maximum buoyancy (N) & 526.8 & $116,548.7$ \\
Weight of the chains (N) & 224.0 & $48,384.0$ \\
Weight of the hoses (N) & 93.7 & $20,239.2$ \\
Weight of the cover net (N) & 12.6 & 3350.7 \\
Weight of the chains & $42.5 \%$ & $42.5 \%$ \\
Maximum buoyancy & $17.8 \%$ & $17.8 \%$ \\
Weight of the hoses & $2.4 \%$ & $2.4 \%$ \\
Meigimum buoyancy & & \\
\hline Maximum buoyancy & & \\
\hline
\end{tabular}

\subsubsection{Experimental Measurements and Analysis}

To investigate the deformation in the experiments, floating up and sinking performance of this hose net using for catch-hauling, fifteen depth meters (DEFI2-D, JFE Advantech Co., Ltd., Hyogo, Japan. 1\% FS, $0.6 \mathrm{~N}$ in water) was attached to the hose net (Figure 3a) and the time step for recording was set as $1 \mathrm{~s}$.

Two air tubes connected the hose net to the flow meter, as indicated in Figure 4, and the tube length was about $10 \mathrm{~m}$. An air compressor was attached to the flow meter, which was used to control the volumes of input and exhaust air, and to measure the airflow rate. A snapshot obtained during the experiment is shown in Figure 5. After configuring the hose net shape, the net sunk to a depth of $4.6 \mathrm{~m}$ with the lifting plate. The hose net sank and floated many times. An underwater circular fisheye camera was used to record the hose net floating up and down. 


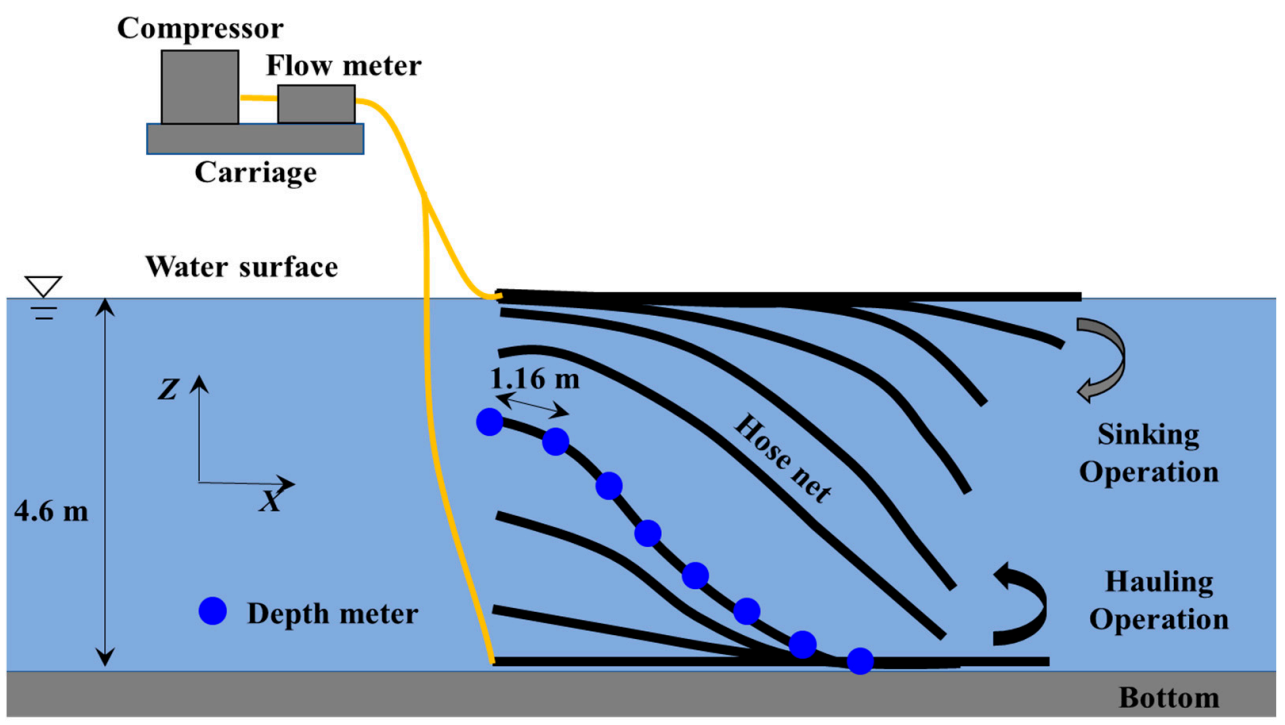

Figure 4. Side-view schematic of the experimental setup.

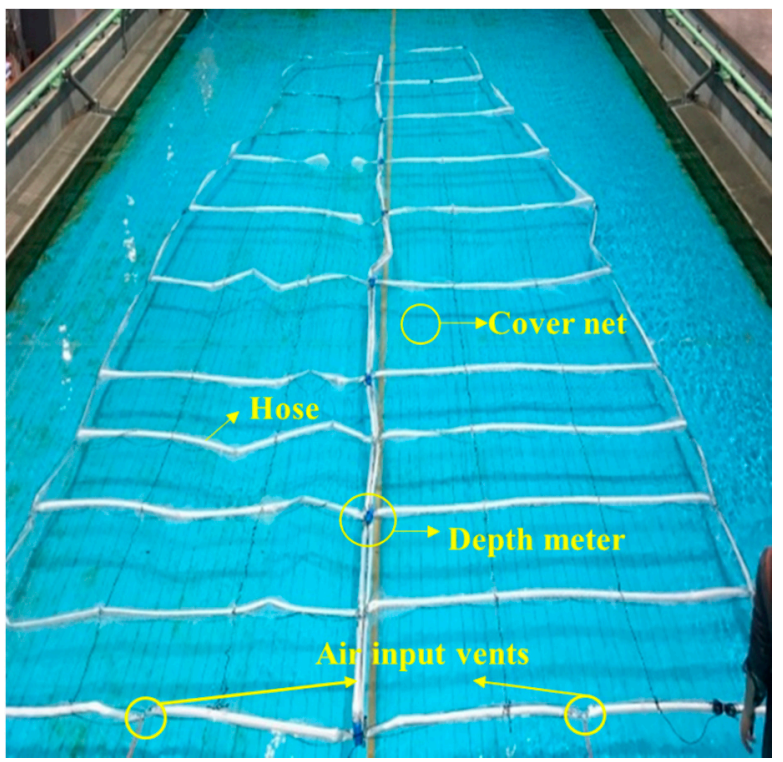

Figure 5. Photograph taken during the experiment.

In the on-site operation, the volumes of air in the hose determine the shape of the hose net. In addition, due to the expansion of air during the floating up, the pressure in the hose net may be higher than atmospheric pressure when the valve is closed, which may cause excessive air to be discharged when the hose net sinks. Therefore, the experimental conditions were considered as follows:

(1) Volumes of input air and exhaust air (varied from 0 to $52 \mathrm{~L}$ in a $4 \mathrm{~L}$ increment);

(2) Initial pressure of the air compressor during air injection (varied from 0.05 to $0.3 \mathrm{MPa}$ in a $0.05 \mathrm{MPa}$ increment);

(3) Inner pressure before exhaust (varied from 0.025 to $0.125 \mathrm{MPa}$ in a $0.025 \mathrm{MPa}$ increment).

The depth meter values of numerous points (X-and Z-coordinates) on the hose net were used to estimate the two-dimensional geometry of the hose net. The Z-coordinates of the depth meter points were collected directly from the depth meters, and the $X$-coordinates were determined by assuming that all horizontal displacements were in the X-direction and that the connecting two points were a straight line (Figure 6). It was feasible to determine 
the subsequent horizontal displacement by knowing the distance between the two depth meters using the initial point air input side as the origin.
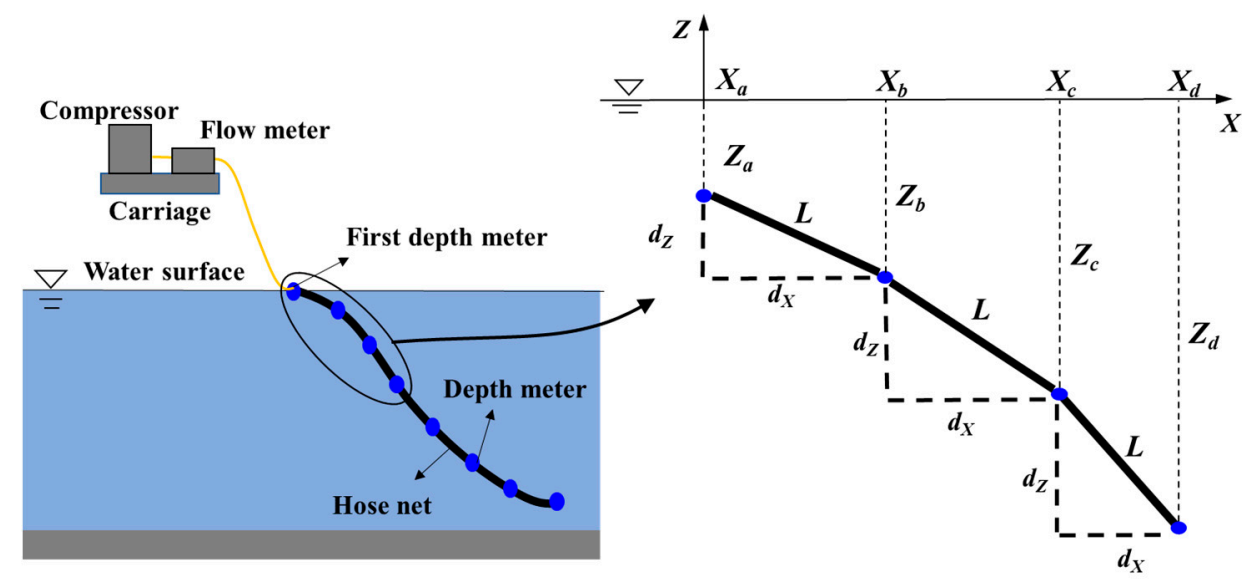

Figure 6. Estimating the method of two-dimensional geometry of the hose net.

\subsection{Catch-Hauling Tests Using Live Fish}

\subsubsection{Box Chamber Net and Flexible Hose Net Models}

To investigate the catch-hauling performance, we conducted experiments using live fish in a small water tank because the installation of animals is prohibited in the Ocean Engineering Basin. A model of a box chamber net and a flexible hose net model were designed with a length scale ratio of $1 / 60$. Figure 7 shows an overview of the box chamber net and hose net models. The box chamber netting was made of polyester. The netting has a mesh size of $1.16 \mathrm{~cm}$, the twine diameter was $0.05 \mathrm{~cm}$. For the flexible hose net, the details are listed in Tables 2 and 3. The length and width of the hose net were 1/60 of the full-scale net. However, because the hose with 1/60 diameter of the full-scale net was too small, it was difficult to create the model. The weight of the chains, about $42.5 \%$ of the maximum buoyancy, was determined using a 1/6 model and a water tank experiment.

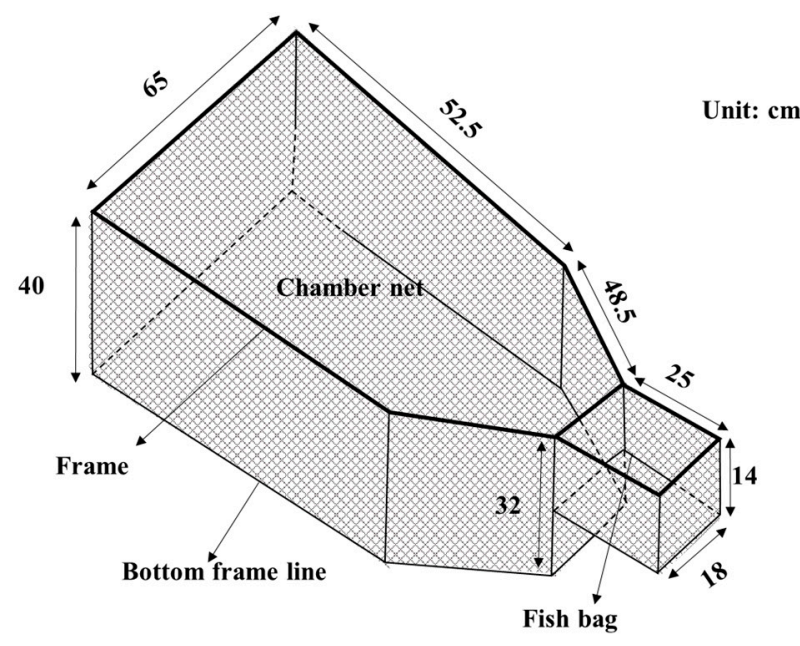

(a) Box chamber net model

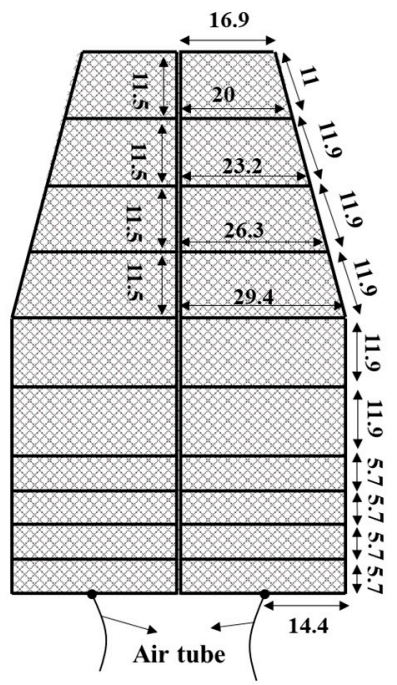

(b) Flexible hose net model

Figure 7. Schematics of the box chamber net and flexible hose net model. 
Table 2. Materials of the $1 / 60$ chamber net and hose net used in catch-hauling tests.

\begin{tabular}{ccccc}
\hline & Material & Density & Mesh Size & Twine Diameter \\
\hline Box chamber net & polyester & $1380 \mathrm{~kg} / \mathrm{m}^{3}$ & $11.6 \mathrm{~mm}$ & $0.5 \mathrm{~mm}$ \\
Hose net & polyester & $1380 \mathrm{~kg} / \mathrm{m}^{3}$ & $3.8 \mathrm{~mm}$ & $0.4 \mathrm{~mm}$ \\
Hose & rubber & $1522 \mathrm{~kg} / \mathrm{m}^{3}$ & $/$ & $/$ \\
Chain & $/$ & $21 \mathrm{~g} / \mathrm{m}$ & $/$ & $/$ \\
\hline
\end{tabular}

Table 3. Physical parameters of the $1 / 60$ hose net used in catch-hauling tests.

\begin{tabular}{cc}
\hline Physical Parameters & Value \\
\hline Diameter of the Hose (cm) & 0.8 \\
Maximum buoyancy (N) & 4.7 \\
Weight of the chains (in the air) (N) & 2.0 \\
Weight of chains / maximum buoyancy (\%) & 42.5 \\
Weight of the hose net (in water) (N) & 0.8 \\
The remaining maximum buoyancy (N) & 1.9 \\
\hline
\end{tabular}

\subsubsection{Live Fish}

To set reasonable experimental situations and choose appropriate experimental fish, we considered the catch harvest situation at a set-net fishing ground in Ajiro, Shizuoka prefecture, Japan. The newly built automated net-hauling system will be applied here. The most common species harvested are Japanese jack mackerel (Trachurus japonicas), Atlantic mackerel (Scomber scombrus), and Mahi-mahi (Corypaena hippurus); the fork lengths of the prototype fish are $0.13-0.23,0.3-0.5$, and $0.5-2 \mathrm{~m}$. Based on the length scale ratio, the fork length range of the experiment fish was:

$$
\begin{gathered}
\frac{L_{f m}}{L_{f f}}=\lambda_{l 60}=\frac{1}{60} \\
L_{f m}=L_{f f} \times \lambda_{l 60}=0.022 \mathrm{~cm}-3.3 \mathrm{~cm}
\end{gathered}
$$

where $L_{f m}$ represents the fork length of the experimental fish and $L_{f f}$ for prototype fish. Although fish with a fork length of $3.3 \mathrm{~cm}$ may be used in the experiment, the prototype fish was $2 \mathrm{~m}$ long, which is not common in set-net fishing. The experimental fish with fork length below $1 \mathrm{~cm}$ can represent the most fish in the full-scale set-net. However, this kind of fish can escape through the hole of the net in the model. Therefore, weight and swimming speed were mainly considered to choose the experimental fish.

There are three kinds of experimental fish, Japanese wakin goldfish, fringetail goldfish and pearl scale goldfish, were used. The body length, weight, and swimming speed of the three kinds of experimental fish are summarized in Table 4 . The total number of fish used in the experiment was 20. The swimming speed of the experimental fish ranged from $0.17-0.63 \mathrm{~m} / \mathrm{s}$ [23]. According to Froude's similarity, this can correspond to the swimming speed of common species captured at Ajiro set-net fishing ground.

Table 4. Three kinds of experimental fish.

\begin{tabular}{ccccc}
\hline Species & $\begin{array}{c}\text { Body Length } \\
(\mathbf{c m})\end{array}$ & $\begin{array}{c}\text { Weight } \\
\mathbf{( g )}\end{array}$ & $\begin{array}{c}\text { Tail Beat } \\
\text { Frequency } \mathbf{( H z )}\end{array}$ & $\begin{array}{c}\text { Swimming } \\
\text { Speed }(\mathbf{m} / \mathbf{s})\end{array}$ \\
\hline $\begin{array}{c}\text { Japanese wakin goldfish } \\
\text { (small) }\end{array}$ & $4 \pm 0.5$ & $4.2 \pm 0.3$ & 20 & $0.42-0.48$ \\
Japanese wakin goldfish & $7.2 \pm 0.3$ & $15 \pm 0.5$ & 15 & $0.62-0.68$ \\
(big) & $5 \pm 0.5$ & $12 \pm 0.5$ & 8 & $0.22-0.26$ \\
$\begin{array}{c}\text { Fringetail goldfish } \\
\text { Pearl scale goldfish }\end{array}$ & $3 \pm 0.5$ & $3.5 \pm 0.2$ & 12 & $0.18-0.25$ \\
\hline
\end{tabular}




\subsubsection{Experimental Conditions}

The depth of the water was $0.44 \mathrm{~m}$. The water temperature was $22{ }^{\circ} \mathrm{C}$, which is a comfortable temperature for goldfish and does not interfere with goldfish activities. In this experiment, due to the limitations of the compressor, we used a syringe instead of the compressor to input air to a hose. Three levels of hauling up speeds, slow, medium and high, were tested, and each hauling up speed was tested thrice. Since the time for floating up to the $1 / 6$ scale hose net was between 90 and $140 \mathrm{~s}$, that of the $1 / 60$ scale hose net should be between 29 and $44 \mathrm{~s}$ according to Froude scaling law. The speeds are summarized in Table 5 . The total floating up time was shorter in case 1 ; however, it is within the same level as the $1 / 6$ scale hose net case in cases 2 and 3. During each experimental case, fish movements were also recorded simultaneously. An example is illustrated in Figure 8.

Table 5. Experimental cases.

\begin{tabular}{lccc}
\hline \multicolumn{1}{c}{ Case } & Case 1 (High) & $\begin{array}{c}\text { Case 2 } \\
\text { (Medium) }\end{array}$ & Case 3 (Low) \\
Time & 5 & 10 & 20 \\
\hline Time for air input side floating up (s) & 9 & 15 & 21 \\
Time for the rest part floating up (s) & 14 & 25 & 41 \\
Total time for floating up (s) & 0.03 & 0.02 & 0.01 \\
Average floating up speeds (m/s) & & \\
\hline
\end{tabular}

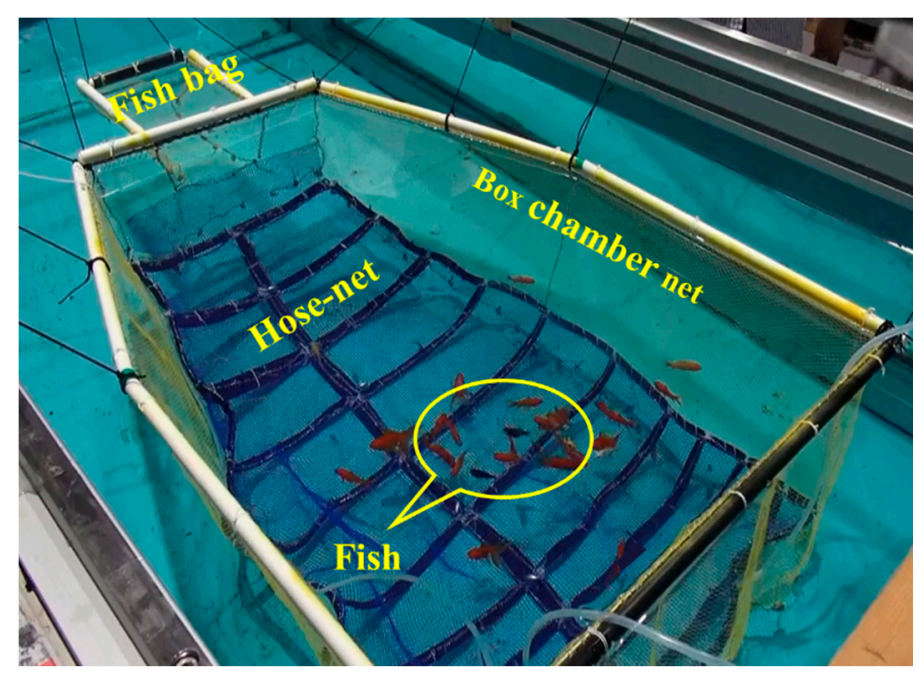

Figure 8. An example of the photographs captured during the experiment.

\section{Results and Discussion}

\subsection{Effects of the Air Volumes on the Two-Dimensional Deformation of Hose Net}

Figure 9a shows various images of the hose net during flotation. The hose net floated up with air injected in, which can be taken advantage of to drive and corner the fish. The configuration curves under the floating up operations with different volumes of air are shown in Figure 9b. Obviously, at air volumes equal to or lower than $16 \mathrm{~L}$, the hose net did not float to the surface, and only the air input side floated up, while the rear part was still kept at the bottom of the water tank. As the air increased, the front part of the hose net gradually floated to the surface, and the underwater part is thought to induce the catch to enter the fish bag. The steeper the curve, the easier the fish are cornered. The entire hose net floated to the water surface when the air volume was $52.0 \mathrm{~L}$ (maximum). 


\section{(a) Images}

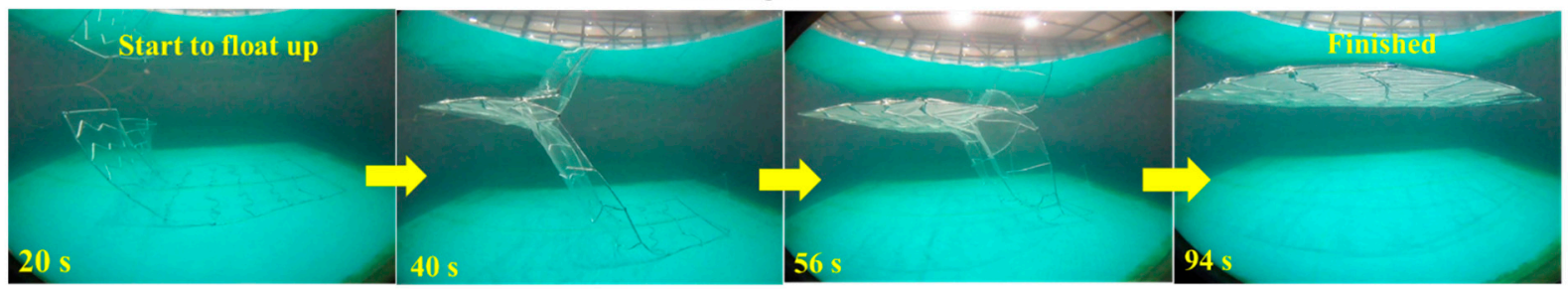

(b) Two-dimensional Deformation

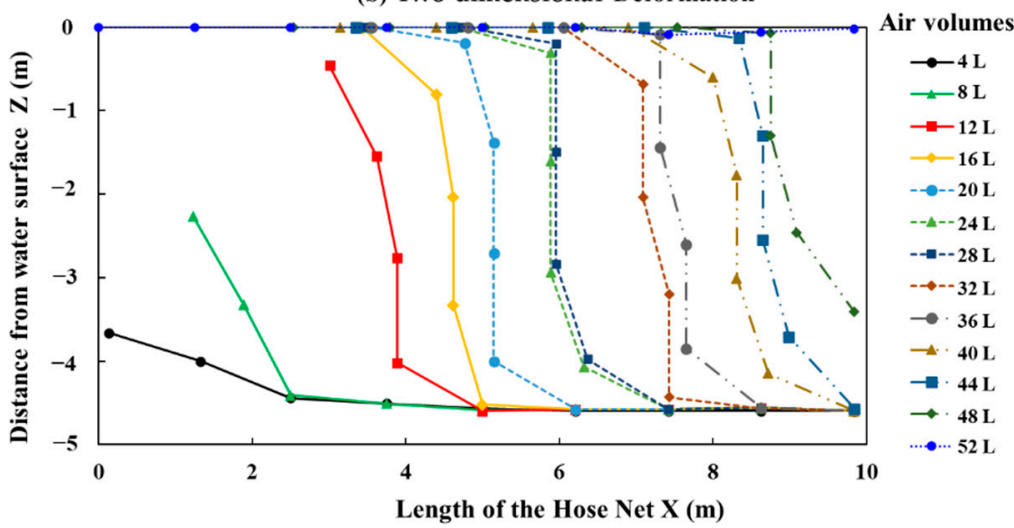

Figure 9. (a) Time-series images during the floating up process. (b) Two-dimensional deformation with different volumes of air in the floating up process.

After catch harvesting, the hose net sank by natural exhaust (Figure 10a). The configuration curves for various air volumes are shown in Figure 10b. The high similarity could be found at air volumes lower than $40 \mathrm{~L}$ by comparing the configuration curves of hose net with the same volume of air in the floating and sinking down process; high similarity could be found, which means that the sinking down process can be treated as the reverse process of floating up. It can be concluded that the deformation of the hose net mainly depends on the volume of air within it, and the direction of airflow or the airflow rate has almost no noticeable influence on the final deformation of the hose net when the air volumes were more than $40 \mathrm{~L}$; however, the hose net could stay afloat on the water surface because its buoyancy was greater than its weight.

Due to the limitations of the experimental conditions, the analysis was limited to two-dimensional deformation of the hose net. However, the local buoyancy distribution affects the three-dimensional shape of the hose net, which is closely related to the capture efficiency. In addition, the hose is in a flat state underwater pressure, and gradually expands as the air enters, not only the buoyancy changes but also the bending strength of the hose. Air exhausting is the opposite process. The bending stress distribution will affect the safety of the hose net, but it is difficult to determine through water tank experiments. Future research should include: establishing a three-dimensional finite element model of hose net, coupling the movement model of hose net with the air flow model in the hose, and analyzing and evaluating the buoyancy and bending stress distribution. 
(a) Images

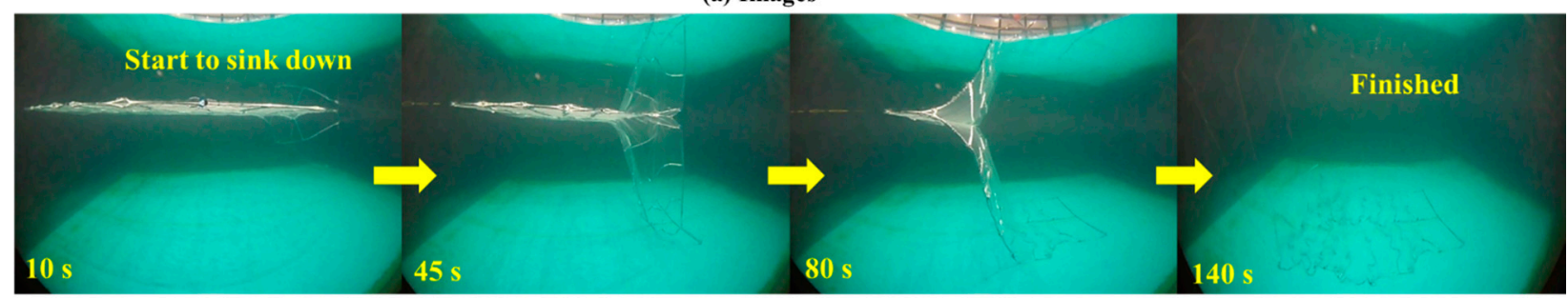

(b) Two-dimensional deformation

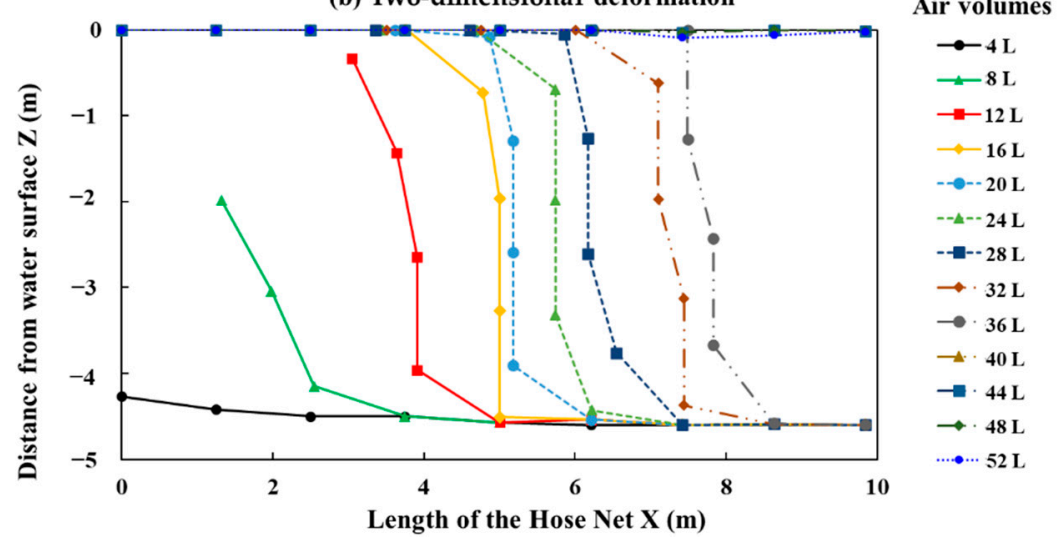

Figure 10. (a) Time-series images during the sinking down the process. (b) Two-dimensional deformation with different volumes of air in the sinking up process.

\subsection{Effects of Initial Pressure of Air Compressor on the Floating Speed}

The air input side was characterized as $X=0 \mathrm{~m}$, the middle of the hose net was described as $X=5 \mathrm{~m}$, and the rear side was described as $X=9.84 \mathrm{~m}$, based on the coordinates established in the experiment.

The floating motions of these three positions were acquired, and the relationships between vertical displacement and time are shown in Figure 11. The motion with acceleration was found around 4 to $4.6 \mathrm{~m}$ below the water surface, whereas the floating at the speed of the hose net becomes almost uniform between 0 to $4 \mathrm{~m}$ below the water surface. It means that the buoyancy, weight, and hydrodynamic drag force were balanced. The floating up speed was calculated by assuming that it linearly varies with time. The floating speed of the air input side was smaller in the case of $0.05 \mathrm{MPa}$. Since the pressure at $4.6 \mathrm{~m}$ below the water surface is $0.045 \mathrm{MPa}$, the small difference between the pressures at the compressor and $4.6 \mathrm{~m}$ below the water surface reduced the air transportation rate. The pressure loss of the air tube with the length of $10 \mathrm{~m}$ between the compressor and the hose net is likely to be small because the air was injected successfully even with a $0.005 \mathrm{MPa}$ difference. There was less difference in the floating speed of the hose net in the case of higher initial pressures of the compressor. When the hose was fully expanded, the buoyancy reached a maximum, resulting in the uniform motion of the hose net. The floating speed of the middle part gradually increased with increasing initial pressure of the compressor and is likely to depend on the airflow rate. The initial pressure of the air compressor had almost no effect on the motion of the rear side because when the airflow arrived at the rear side, the flow rate was almost the same regardless of how fast the initial airflow rate was in the experiment. 

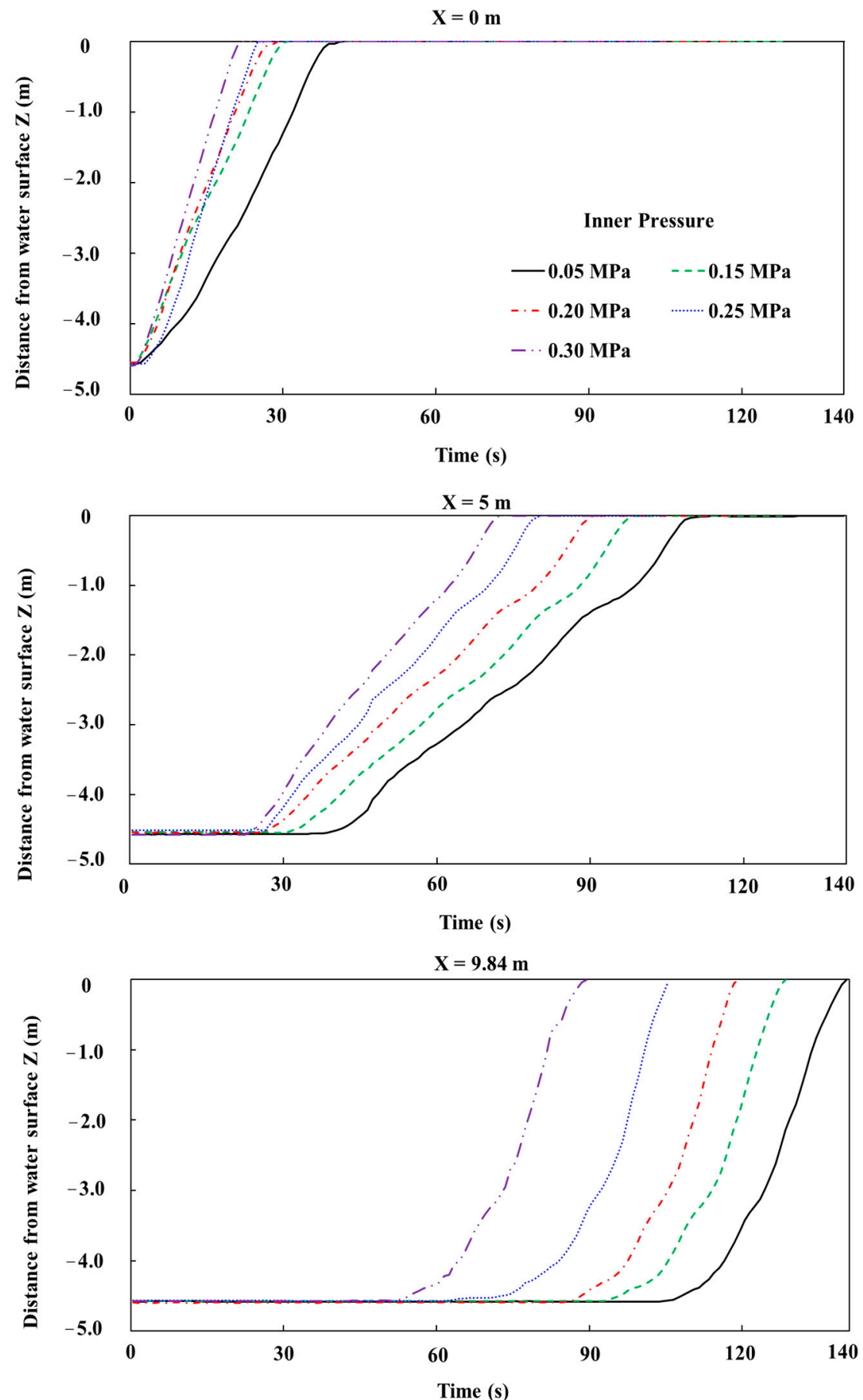

Figure 11. Vertical motion of the air input side $(X=0 \mathrm{~m})$, the middle $(X=5 \mathrm{~m})$, and the rear side $(X=9.84 \mathrm{~m})$ of the hose net.

The average floating speeds of the hose net are summarized in Table 6 . It should be noted that the higher the initial pressure of the air compressor, the less time required for hauling up process. The floating up speed of the hose net can be adjusted in practice by changing the initial pressure of the air compressor. 
Table 6. Floating speed of the model hose net.

\begin{tabular}{|c|c|c|c|c|}
\hline $\begin{array}{l}\text { Floating Speed } \\
\text { Initial Pressure of } \\
\text { Air Compressor (MPa) }\end{array}$ & $\begin{array}{l}\text { Air Input } \\
\text { Side } \\
(X=0)(\mathrm{m} / \mathrm{s})\end{array}$ & $\begin{array}{l}\text { Middle Part } \\
(\mathrm{X}=5.0 \mathrm{~m}) \\
(\mathrm{m} / \mathrm{s})\end{array}$ & $\begin{array}{c}\text { Rear Side } \\
(X=9.84 \mathrm{~m}) \\
(\mathrm{m} / \mathrm{s})\end{array}$ & $\begin{array}{l}\text { Average } \\
\text { Floating Up } \\
\text { Speed }(\mathrm{m} / \mathrm{s})\end{array}$ \\
\hline 0.05 & 0.11 & 0.06 & 0.12 & 0.03 \\
\hline 0.15 & 0.14 & 0.07 & 0.12 & 0.04 \\
\hline 0.20 & 0.16 & 0.07 & 0.12 & 0.04 \\
\hline 0.25 & 0.18 & 0.08 & 0.12 & 0.04 \\
\hline 0.30 & 0.21 & 0.09 & 0.12 & 0.05 \\
\hline
\end{tabular}

\subsection{Effects of Initial Inner Pressure on the Time for Sinking Down}

The sinking down process consisted of two stages. When the vent was opened, the air was exhausted with high velocity, and inner pressure decreased. The second stage was sinking gradually, beginning from the rear side, similar to a reverse floating up. If the initial inner pressure is higher, it will require more time to eject much air. However, the air ejection rate may be increased by the difference between the initial inner and atmospheric pressure, resulting in less time to eject air. As shown in Figure 12, the orange columns represent the time spent for sinking motion, and blue columns show air exhausting. It was found that the movement time was $140 \mathrm{~s}$, almost the same in the four cases. However, the larger the inner pressure, the longer it took for the inner pressure to decrease, which means more time was spent on air exhausting. With higher initial inner pressure, the total time spent for sinking operation was longer. In practical operation, to enhance the efficiency of the sinking down operation, the initial inner pressure should be relatively small.

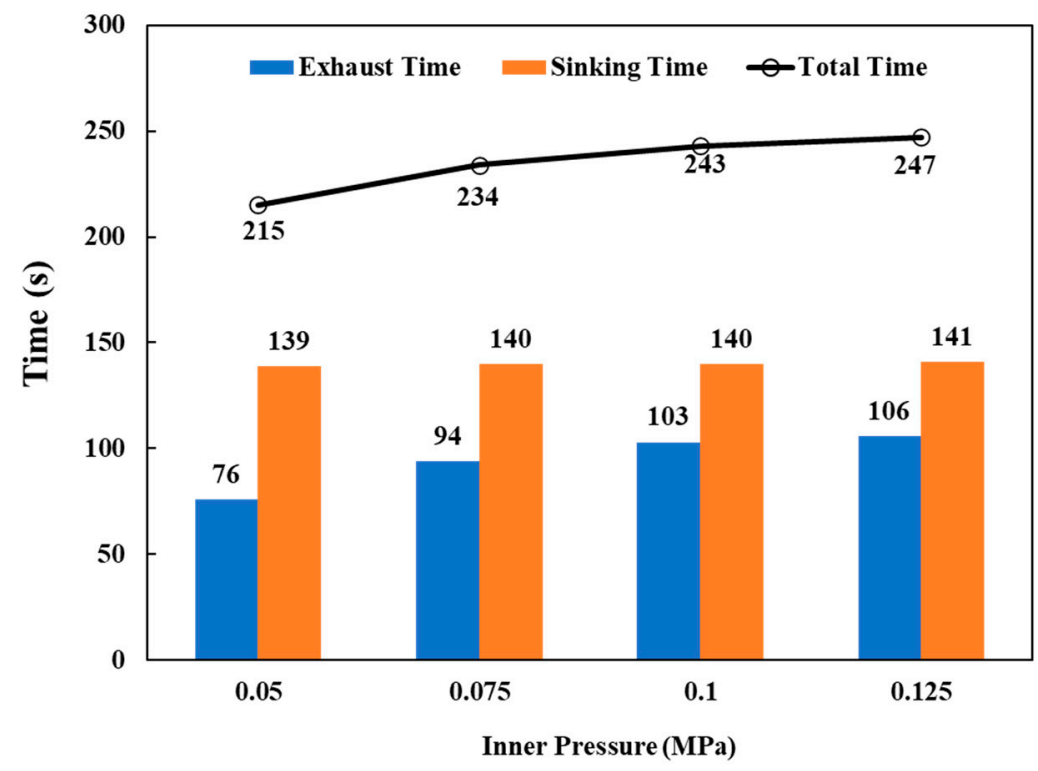

Figure 12. Time for sinking operation with different initial inner pressure.

These findings suggest that understanding the time variation in the airflow in the hose net will be helpful in the improvement and optimization of the novel automated catchhauling device. We could control the floating speed of the hose net by changing the initial pressure of the air compressor in practical operation. The air input end should float up quickly to prevent the fish from escaping. Furthermore, the chamber net was not included in this experiment. In particular, the chamber net and hose net easily deformed under wave and water flow, influencing the floating up and sinking down speed. Therefore, future research should be conducted under waves and currents to provide a reliable theoretical basis for its application. 


\subsection{Catch-Hauling Performances}

As an example, Figure 13 shows the fish school motion in the Case 2 hauling up operation. The hose net gradually floated up as the air was injected in. As the hose net was floated, the fish were directed to the fish bag. We also observed from the image that catching failure was caused by fish escaping through the gap between the hose net and the box chamber net. Figure 14 shows two main phenomena of catching failure. One was that fish escaped through the gaps between the hose net and the box chamber net. The other was that fish were stuck on the floated up hose net before swimming forward to avoid the hose net. Overall, the fish-harvesting rate (i.e., the ratio of the number of fish entering the catching pot to the total number of the fish used) in Case 2 (medium speed) was the highest, $78.5 \%$, while the harvest rate in Case 1 (high speed) is the lowest, $55 \%$.

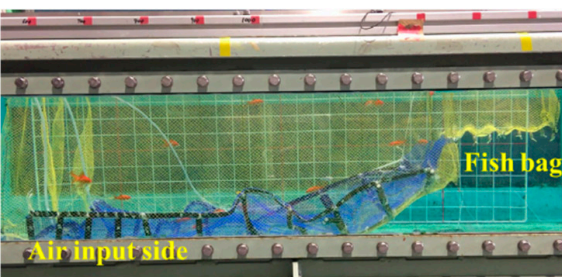

$3 \mathrm{~s}$

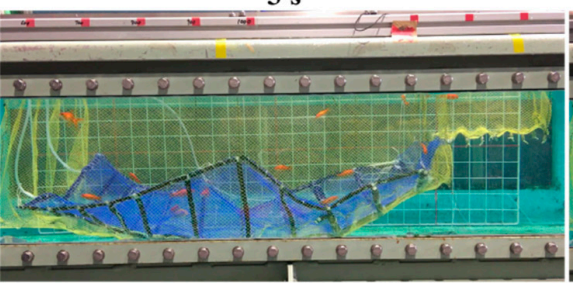

$6 \mathrm{~s}$

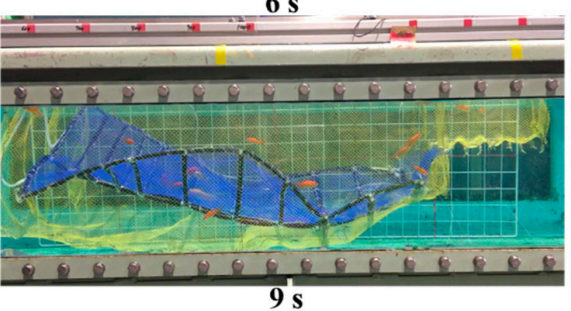

$9 \mathrm{~s}$

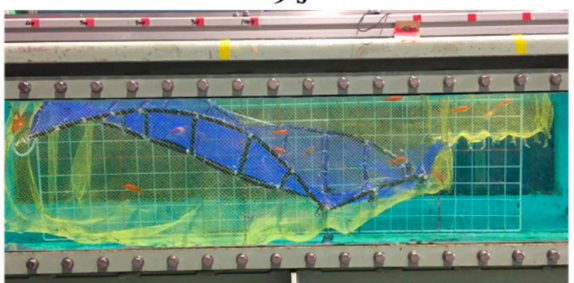

$12 \mathrm{~s}$

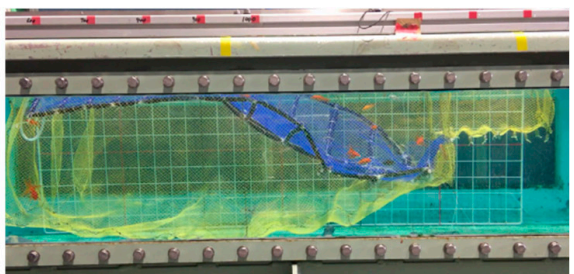

$15 \mathrm{~s}$

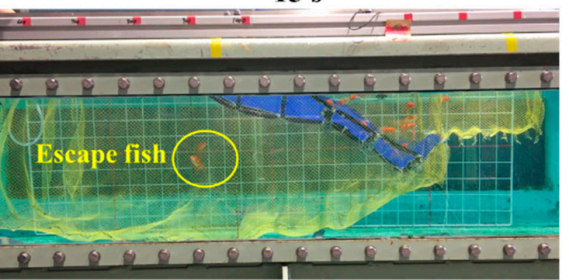

$18 \mathrm{~s}$

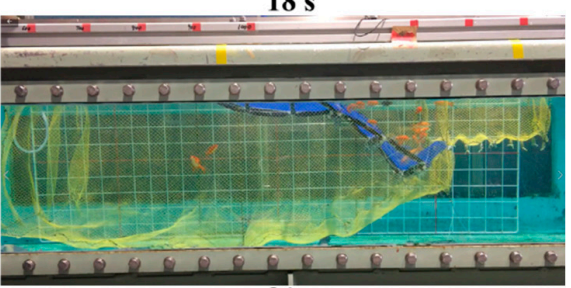

$21 \mathrm{~s}$

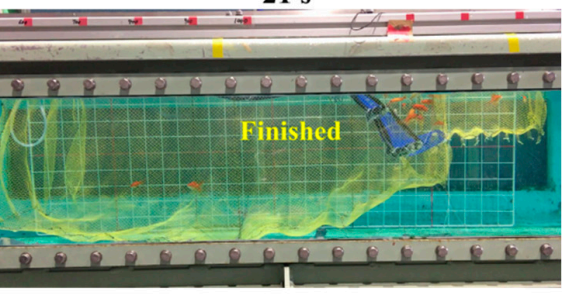

$24 \mathrm{~s}$

Figure 13. Fish school behavior in the hauling up process for case 2 .
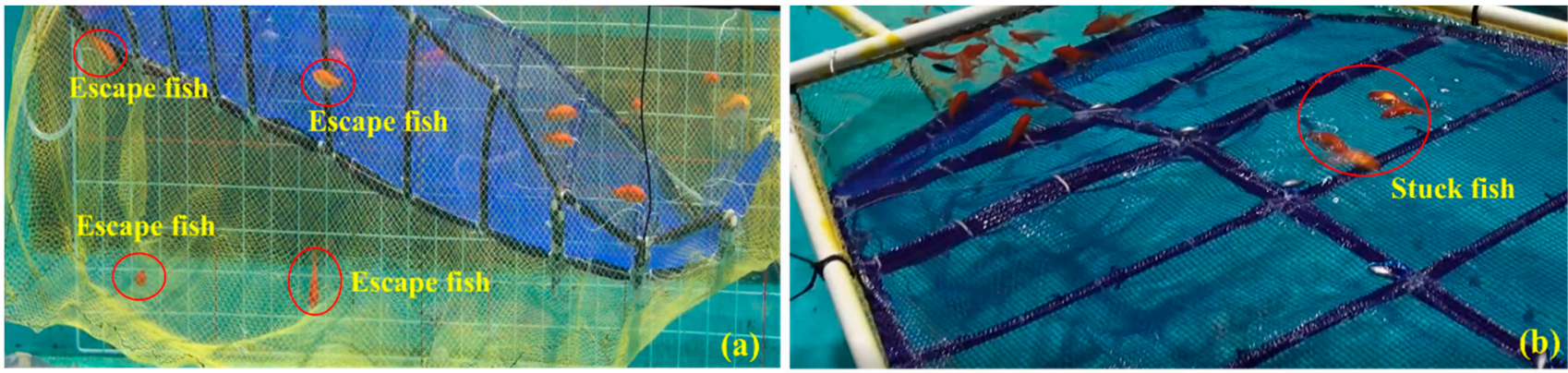

Figure 14. (a) Fish escaped through the gaps. (b) Fish stuck on the hose net and unable to swim forward. 
The findings of the experiment revealed that the average floating speed impacts on the existing automated net-hauling system's fish-harvesting rate. The fish-harvesting rate was the highest among the three examples of when the average floating speed was $0.02 \mathrm{~m} / \mathrm{s}$ (case 2 in Table 5). Although the fish escape problem occurred in each experiment case, the fish-stuck problem in case 1 (high speed, $0.03 \mathrm{~m} / \mathrm{s}$ ) is the main cause of the lower harvest rate. This means that if the hose net floated up too quickly, the fish would not be able to swim forward in time to avoid the moving net.

The analysis of the floating up and sinking down time was performed using the $1 / 6$ scale model. However, due to the limitations of the experimental equipment, the pressure could not be changed to carry out the experiment using the 1/60 model, so we could not compare the results of the two models. Combining the results of Sections 3.2 and 3.3 above, it can be concluded that to achieve the function of driving the fish, after the air input end-flats on the water surface, the floating speed of the rest of the hose net should be adjusted by controlling the airflow speed according to the fish swimming speed to avoid the fish-stuck problems.

Additionally, the set-net is a passive trap net; the fish behavior in the chamber net is a significant factor that affects the fish-harvesting rate of the automatic fish-harvesting system, which mainly depends on the species and size of the fish. Sea trials help understand fish behavioral characteristics, but the field investigation incurs a financial cost and personnel power. In addition, experiments using live fish in the laboratory restrict the species and size of fish, and have strict requirements for fish health management. The numerical models of fish school behavior are expected to solve this problem [3,9] because the behavior of different species and sizes of fish can be simulated. It can also account for the entire set-net structure to explore the catch efficiency comprehensively.

\section{Conclusions}

In this paper, a unique automated catch-hauling apparatus based on a flexible fire hose with a cover net was developed to deal with aging populations. When using this unique method in a set-net, we conducted a series of water tank experiments and catch-hauling tests to evaluate the performance of this hose net, including the deformation shape of the hose net, floating up and sinking down speeds, and fish school behavior.

The newly created hose net can gradually float up in a shape configuration with a significant inclination angle, indicating that the curve might be used to corner and harvest the fish. The volume of air in the newly designed hose net determines how much it deforms.

Floating up speeds of the hose net could be controlled by the initial pressure of the air compressor. With higher initial inner pressure, the total time spent for sinking down operation was longer. The higher the initial internal pressure, the longer the total time spent for the sinking operation.

The fish were driven to the fish bag as the hose net was floated during the catchhauling tests using live fish. There were two main causes of catching failure: (1) fish escaped through the gaps, and (2) fish became trapped on the hose net, unable to move ahead. This is primarily determined by the floating speed of the hose net and the swimming ability of the fish.

Overall, these findings suggest that the automated catch-hauling device proposed in this study has a high application value in the set-net fishery. In particular, with the introduction of information and communication technology in the fisheries industry, the development prospects of this device are expected. Furthermore, in practical application, sea currents and many other factors may cause substantial problems for the system. Our future work will include laboratory experiments, full-scale testing, and numerical simulations to explore the effects of waves and current flow on the performance of the proposed automated catch-hauling device. 
Author Contributions: Conceptualization, Q.L., Y.M. and Y.L.; methodology, Q.L., D.K., T.Y. and Y.M.; software, Y.L. and S.D.; formal analysis, Y.L., Q.L. and S.D.; investigation, Q.L., Y.L., S.D., Y.M., J.H. and T.Y.; data curation, Q.L.; writing-original draft preparation, Q.L., Y.L. and S.D.; writing-review and editing, J.H., T.Y. and D.K.; visualization, Y.L. and S.D.; supervision, D.K.; project administration, D.K.; funding acquisition, D.K. All authors have read and agreed to the published version of the manuscript.

Funding: This work was supported by JSPS KAKENHI Grant Number JP1801633.

Institutional Review Board Statement: The animal experiments were conducted according to the guidelines of the Declaration of Helsinki, and approved by the Experimental Animal Care and Use Committee of The University of Tokyo (protocol code 01-08, date of approval 30 October 2019).

Informed Consent Statement: Not applicable.

Data Availability Statement: The data are presented in the paper.

Acknowledgments: A part of this work was supported by Grant-in-Aid for Scientific Research (B) in Japan Society for the Promotion of Science (Grant Number: 18H01633). We would like to show appreciation to the graduate students of Kitazawa Laboratory for their assistance in the experimental work.

Conflicts of Interest: The authors declare no conflict of interest.

Ethics Statements: The animal experiments were reviewed and approved by the Experimental Animal Care and Use Committee of The University of Tokyo.

\section{References}

1. He, P.G.; Chopin, F.; Suuronen, P.; Ferro, R.S.T.; Lansley, J. Classification and Illustrated Definition of Fishing Gears; FAO Fisheries and Aquaculture Technical Paper No. 672; FAO: Rome, Italy, 2021.

2. He, P.G.; Inoue, Y. Large-scale fish traps: Gear design, fish behavior, and conservation challenges. In Behavior of Marine Fishes: Capture Processes and Conservation Challenges; He, P., Ed.; Wiley-Blackwell: Ames, IA, USA, 2010; pp. $159-181$.

3. Takahashi, Y.; Komeyama, K. Simulation of the capture process in set net fishing using a fish-schooling behavior model. Fish Sci. 2020, 86, 971-983. [CrossRef]

4. Hiramoto, T. Historical changes of set net type in Sagami bay-2. Big set net type-(1). Bull. Kanagawa Prefect. Fish Exp. Stn. 1997, 2, 25-47.

5. Wan, R.; Guan, Q.L.; Li, Z.G.; Hu, F.X.; Dong, S.C.; You, X.X. Study on hydrodynamic performance of a set-net in current based on numerical simulation and physical model test. Ocean Eng. 2020, 195, 106660. [CrossRef]

6. Ministry of Agriculture, Forestry and Fisheries of Japan. Available online: https://www.maff.go.jp/j/tokei/census/gyocen_ illust2.html (accessed on 2 June 2021).

7. Ministry of Agriculture, Forestry and Fisheries of Japan. 2020 Fishery and Aquaculture Production Statistics. Available online: https:/ / www.maff.go.jp/j/tokei/kouhyou/kaimen_gyosei/index.html (accessed on 1 July 2021).

8. Suuronen, P.; Chopin, F.; Glass, C.; Løkkeborg, S.; Matsushita, Y.; Queirolo, D.; Rihan, D. Low impact and fuel efficient fishing-Looking beyond the horizon. Fish. Res. 2012, 119, 135-146. [CrossRef]

9. Takagi, T.; Moritomi, Y.; Iwata, J.; Nakamine, H.; Sannomiya, N. Mathematical model of fish schooling behaviour in a set-net. ICES J. Mar. Sci. 2004, 61, 1214-1223. [CrossRef]

10. Inoue, Y.; Watanabe, T. Fish behaviour in the capturing process of the one-trapped and the two-trapped set-net. Nippon Suisan Gakkaishi. 1986, 53, 1738-1744.

11. Inoue, Y. Size and moving behaviour of fish schools around the set-net. Nippon Suisan Gakkaishi. 1987, 53, 1307-1312. [CrossRef]

12. Uchida, K.; Ogawa, H.; Hasegawa, K.; Miyamoto, Y.; Noro, H.; Wada, Y.; Akiyama, S. Monitoring the behavior of young bluefin tuna Thunnus orientalis and yellowtail Seriola quinqueradiata in set nets using ultrasonic biotelemetry. Nippon Suisan Gakkaishi. 2018, 84, 14-22. [CrossRef]

13. Fisheries Agency: The 1st Technology Workshop of Set Net Fishery. Available online: https://www.jfa.maff.go.jp/j/study/ kenkyusidoka/teichi.html (accessed on 12 May 2021).

14. Fukahori, K.; Kasutani, M.; Nishenokubi, H. On the development of an automatic setnet. Bull. Fac. Fish Nagasaki Univ. 1988, 64, 45-51.

15. Zhang, J.B.; Dohi, M.; Yoshida, T.; Kitazawa, D. Investigating the utilization of polyethylene pipe for automated hauling system in set net fishery. Ocean Eng. 2021, 233, 109192. [CrossRef]

16. Suuronen, P.; Siira, A.; Kauppinen, T.; Riikonen, R.; Lehtonen, E.; Harjunpää, H. Reduction of seal-induced catch and gear damage by modification of trap-net design: Design principles for a seal-safe trap-net. Fish. Res. 2006, 79, 129-138. [CrossRef]

17. Hemmingsson, M.; Fjälling, A.; Lunneryd, S.G. The pontoon trap: Description and function of a seal-safe trap-net. Fish. Res. 2008, 93, 357-359. [CrossRef] 
18. Kitazawa, D.; Mizukami, Y.; Hirai, Y. Numerical analysis of the motion of a flexible hose net used for hauling a box chamber. In Proceedings of the ASME 2012 31st International Conference on Ocean, Offshore and Arctic Engineering, Rio de Janeiro, Brazil, 1-6 July 2012. OMAE2012-84151.

19. Kitazawa, D.; Zhang, J.B.; Mizukami, Y.; Hirai, Y.; Hosokawa, T. Experimental study on the motion of a flexible hose net used for fish-harvesting in a set net fishery. J. Mar. Sci. Technol. 2018, 23, 620-632. [CrossRef]

20. Zhou, X.; Mizukami, Y.; Yoshida, T.; Kitazawa, D. Motion analysis of flexible hose based on water tank experiment. In Proceedings of the ASME 2018 37th International Conference on Ocean, Offshore and Arctic Engineering, Madrid, Spain, 17-22 June 2018. OMAE2018-77597.

21. Li, Y.; Mizukami, Y.; Yoshida, T.; Li, Q.; Han, J.L.; Kitazawa, D. Experimental Study on the Motion of a Flexible Hose Net Used in Automated Net-Hauling System. In Proceedings of the ASME 2019 38th International Conference on Ocean, Offshore and Arctic Engineering, Glasgow, Scotland, UK, 9-14 June 2019. OMAE2019-95670.

22. Li, Q.; Li, Y.; Mizukami, Y.; Dong, S.C.; Yoshida, T.; Kitazawa, D. Experimental Study on Fish-Harvest Performance of the Flexible Hose Net. In Proceedings of the ASME 2020 39th International Conference on Ocean, Offshore and Arctic Engineering, Virtual, 3-7 August 2020. OMAE2020-18513.

23. Zhang, J.B.; Kitazawa, D.; Taya, S.; Mizukami, Y. Impact assessment of marine current turbines on fish behavior using an experimental approach based on the similarity law. J. Mar. Sci. Technol. 2017, 22, 219-230. [CrossRef] 